\title{
Utilization of Rumen Mechanical Stimulator as Pseudo Fiber in Ruminant to Minimize Metabolic Problem
}

\section{(Penggunaan Stimulator Mekanis Rumen sebagai Pseudo Fiber pada Ternak Ruminansia untuk Mengurangi Masalah Metabolis)}

\author{
N Nurmeiliasari ${ }^{1,2}$, R Priyanto ${ }^{3}$, DA Astuti ${ }^{4}$, Salundik $^{3}$ and J Takahashi ${ }^{5}$ \\ ${ }^{1}$ Department of Animal Science, Faculty of Agriculture, University of Bengkulu \\ Jl. WR Supratman, Kandang Limun, Bengkulu 38371A, Indonesia \\ ${ }^{2}$ Graduate School of Animal Production and Technology, Bogor Agricultural University \\ ${ }^{3}$ Department of Animal Production and Technology, Bogor Agricultural University \\ ${ }^{4}$ Department of Animal Nutrition and Feed Technology, Bogor Agricultural University \\ Jl. Agatis Kampus IPB Darmaga, Babakan, Bogor 16680, West Java, Indonesia \\ ${ }^{5}$ Graduate School of Animal Science, Obihiro University of Agriculture and Veterinary Medicine, Obihiro, Hokkaido, Japan \\ sari_nurmeiliasari@unib.ac.id
}

(Received 24 November 2016 - Revised 3 Mei 2017 - Accepted 29 Mei 2017)

\begin{abstract}
Feeding high concentrate diet, characterized with high starch and low fiber is applied to increase energy intake for an optimal production performance in ruminants. However, the prevalence of digestive disorder namely ruminal acidosis has been reported as drawback of this feeding strategy. This encourages farmers and nutritionist to supply adequate fiber in the diet to meet minimum dietary fiber requirement. However, feeding high forage diet is reported to give adverse effect on production performance, thus economic loss for farmers. Therefore, some sorts of artificial fiber utilizations have been introduced to reduce the risk of nutritional diseases as well as improving ruminant productivity. The utilization of rumen mechanical stimulator aims to maintain a healthy rumen function in ruminants fed with high concentrate diet. Objective of this article is to review recent development of rumen mechanical stimulators utilization, a pseudo fiber to substitute forage physical function in the rumen of ruminants. This review highlights the use of rumen mechanical stimulators in dairy cattle, beef cattle and sheep with particular attention in rumination time and rumen parameters. In conclusion, rumen mechanical stimulator is attributable to minimize metabolic problem associated with high concentrate feeding by providing mechanical stimulation on the rumen wall.
\end{abstract}

Key words: Nutritional related diseases, rumen mechanical stimulator, rumination time, rumen fermentation

\section{ABSTRAK}

Strategi pemberian pakan konsentrat tinggi dan rendah serat diaplikasikan untuk meningkatkan konsumsi energi demi mendukung tampilan produksi pada ruminansia. Tetapi, kasus metabolic disorder seperti asidosis sub-akut dilaporkan sebagai akibat negatif dari pemberian pakan konsentrat tinggi. Hal ini juga berdampak pada tampilan produksi dan menyebabkan peternak mengalami kerugian finansial. Upaya-upaya untuk menekan pengaruh negatif dari penerapan strategi pemberian pakan konsentrat tinggi dapat dilakukan dengan memperhatikan kecukupan suplai pakan serat. Tantangan yang dihadapi dengan pemanfaatan pakan serat adalah menurunnya tampilan produksi ternak ruminansia. Suatu penelitian telah mengembangkan serat buatan sebagai stimulator mekanis di dalam rumen. Stimulator mekanis ini berfungsi untuk memberikan rangsangan fisik pada dinding rumen sehingga terjadi peningkatan motilitas dan ruminasi yang berkontribusi positif dalam menekan kadar asam yang tinggi akibat fermentasi pakan konsentrat. Artikel ini membahas mengenai aplikasi stimulator mekanis rumen pada ternak sapi perah, sapi potong dan domba. Pembahasan mencakup pengaruh stimulator mekanis terhadap lama ruminasi dan parameter fermentasi rumen. Rangsangan fisik dari serat buatan stimulator mekanis rumen dapat menekan tingkat kejadian asidosis subakut pada peternakan yang memberikan pakan konsentrat tinggi dengan memberi stimuli pada dinding rumen.

Kata kunci: Gangguan kesehatan akibat pakan, stimulator mekanis rumen, lama ruminasi, fermentasi rumen

\section{INTRODUCTION}

Demand on animal protein increases rapidly due to increasing number of human population, urbanization and increasing incomes in developing countries. In order to meet growing needs of cattle products, high concentrate diet feeding strategies have been used by farmers to achieve optimal production performance and maximum genetic potential of livestock; therefore, an efficient productivity of dairy 
and beef cattle. Feeding high percentage of concentrate diet has been reported to have positive effects on weight gain and feed efficiency in beef cattle (Schoonmaker et al. 2010) and buffalo (Helal et al. 2011).

Nevertheless, feeding high grain puts a greater risk for the development of sub-acute ruminal acidosis (SARA), as the amount of volatile fatty acid (VFA) production increases by $19.4 \%$ (Li et al. 2014a) which goes over the animal's ability for absorption (Schwaiger et al. 2013; Gimeno et al. 2015b; Schären et al. 2016). A study on rumen bacteria count of dairy goats challenged with SARA reported an increase by almost two folds in amylolytic bacteria which is dominated by Succinimonas amylolytica and a decrease by $14.97 \%$ in cellulolytic bacteria such as Fibrobacter succinogenes ( $\mathrm{Li}$ et al. 2014a). Moreover, the ruminants are subjected to increases in propionate $(12.22 \%)$ and $25 \%$ increase of acetate and propionate ratio which are followed with an increase in saliva secretion to buffer low rumen $\mathrm{pH}$ level (Schwaiger et al. 2013; Wang et al. 2013; Abdela 2016). In addition, duration of chewing per kg DM decreased linearly (673 vs $404 \mathrm{~min} /$ day) (Li et al. 2014b); it means that there is a decrease in ruminal liquid outflow, thus saliva production (Lechartier \& Peyraud 2010). Those processes lead to acute ruminal acidosis or sub-acute ruminal acidosis that are attributable to low production performance to the ruminants. Therefore, control and management of ruminal acidosis risks should be prioritized in supporting optimal production performance.

Inclusion of dietary fiber is beneficial to support rumen function and minimizing disorder issues due to high concentrate diet (Arelovich et al. 2008; Zebeli et al. 2012b). Zebeli et al. (2008) introduced the concept of physical effective to rumen degradable starch ratio (PRR) to minimize the occurrence of SARA in dairy cattle. The two main components of PRR, physically effective neutral detergent fiber (PeNDF) and rumen degradable starch (RDS) play significant role to determine ruminal acidic level. The PRR score is a ratio of the PeNDF1.18 (obtained by filtering the forage particle at $1.18 \mathrm{~mm}$ ) and RDS from grain. The PRR of 1.45 is ideal to set ruminal $\mathrm{pH}$ at more than 6.2 (Zebeli et al. 2008). Khafipour et al. (2009) mentioned that SARA induced by high dietary concentrate proportion and low PeNDF. Alteration in ratios of PeNDF and RDS given will affect fermentation pattern, inflammatory response and microflora of rumen (Khafipour et al. 2009).

In agreement with previous study, Zebeli et al. (2012b) mentioned that sufficiency of dietary fiber can be determined by using PeNDF which is a representation of chemical fiber content and particle size information. Particle size and chemical content of dietary fiber have effects on dry matter intake (DMI), feeding behavior and ruminal mat formation (Zebeli et al. 2007; Suzuki et al. 2014). A study using different size of forage length particle and high and low forage feeding suggested that forage proportion and forage particle length contribute significantly to saliva production that prevent the cases of acidosis in dairy cattle (Yang \& Beauchemin 2007). Saliva supply to the rumen obtained during chewing in eating activity and during rumination. Rumination is triggered by motility of rumen wall that is observed due to dietary fiber presence in the digesta located in the rumen (Zebeli et al. 2012a).

However, utilization of dietary fiber has adverse effect on DMI due to rumen fill factor of fibrous diet (Arelovich et al. 2008), body weight gain (ArgovArgaman et al. 2014) and results in greater energy cost compared to concentrate (Arelovich et al. 2008). Comparison of feeding high concentrate $(65 \%)$ and high forage $(65 \%)$ diet showed that feeding $65 \%$ concentrate and $35 \%$ forage led to an increase in body weight by $4 \mathrm{~kg} / \mathrm{head} /$ week. In contrast, a low concentrate diet feeding group (35\% concentrate: $65 \%$ forage) experienced great loss of $6.6 \mathrm{~kg}$ body weight/ head/week.

Eventhough feeding roughage has greater energy expenditure, minimum requirement of dietary fiber in a high concentrate feeding should be provided in supporting an ideal rumen environment for optimum production performance (Arelovich et al. 2008). Therefore, rumen mechanical stimulator that mimics physical function of fiber may be used as an alternative solution to address problems in high concentrate feeding without negative effects on production performance.

This article illustrates the role of the rumen mechanical stimulators in increasing motility of rumen wall that facilitates an increase in saliva supply through rumination activities. This is a feasible solution for high concentrate diet feeding associated problems.

\section{THE IMPORTANCE OF FEEDING HIGH CONCENTRATE DIET AND METABOLIC DISORDER ISSUES}

Efficiency of production in ruminant has been major issues in both industries as it determines profit for the producers. Feeding is a component that presents variable cost, which interferes a lot with the profitability. An efficient utilization of feed energy is one of the keys of successful livestock production. Feeding high concentrate diet is reported to be more economical compared to conventional feeding system as roughage feeding has greater cost per unit energy obtained (Arelovich et al. 2008). Baraghit et al. (1999) mentioned that the economic efficiency of production 
was $16.6 \%$ better with feeding high concentrates than feeding high roughage. Moreover, some studies reported that this feeding strategy improves feed efficiency due to its high fermentable diet (Turgeon et al. 2010; Gomes et al. 2014).

Feeding ad libitum concentrate diet has been reported to have $24.2 \%$ higher live weight gain in steers compared to total mixed ratio consisted of 50\% alfalfa hay, $10 \%$ straw and $40 \%$ corn-fed steers (Blanco et al. 2014). In terms of meat quality, there are variations of results as sources, characteristics and chemical composition of concentrate ingredients are varied. Schoonmaker et al. (2010) observed increases in weight gain, carcass percentage, longissimus muscle area, marbling score and poly unsaturated fatty acid (PUFA). Similarly, Fruet et al. (2016) mentioned that C18:2n6, n6/n3, thiobarbituric acid reactive substance (TBARS), total lipid, lightness, and yellowness index of longissimus lumborum portion were affected by high concentrate feeding in ewes. However, this treatment did not affect fatty acid profile of beef meat (Horcada et al. 2016). Research in dairy cattle reported that milk yield, fat, protein and lactose were higher in low forage feeding groups (Argov-Argaman et al. 2014). Contributions of high concentrate diet on production performance of ruminants derived from high energy density supply as material for microbial fermentation in the rumen (Zanton \& Heinrichs 2016; Wang et al. 2017b).

Eventhough there are some benefits of feeding high concentrate diet, nutritional related disorder has been reported as a drawback of this feeding strategy (Gonzales et al. 2012). Nutritional disorder due to high concentrate feeding is indicated by some significant changes in $\mathrm{pH}$, gas production, VFA concentration and population of ruminal (Mickdam et al. 2016). One of mostly discuss nutritional disorder due to high concentrate feeding and or low physical structure of feedstuff is ruminal acidosis (De Campeneere et al. 2002; Metzler-Zebeli et al. 2013; Kljak et al. 2017; Snyder \& Credille 2017).

Ruminal acidosis or lactic acidosis is defined as rumen digestive disorder characterized with low ruminal $\mathrm{pH}$ that is caused by high production rates of short chain fatty acid produced from highly fermentable diet consumption (Bramley et al. 2008). Series of events related to the initiation of ruminal acidosis begins with introduction of huge amount of high energy density diet. This induces an increment in bacteria growth rates; thus increases in total VFA. Active fermentation and VFA production cause a decrease in rumen $\mathrm{pH}$ and increase in lactic acid production. High intake of fermentable diet supplies energy for rapid growth of Streptococcus bovis, a lactic acid producer. Production of lactic acid is plateud as the rumen $\mathrm{pH}$ reaches 5.5, a point where Lactobacillus starts to grow rapidly. S. bovis produces less lactic acid when the $\mathrm{pH}$ is below 5.0 and together with Lactobacillus, both bacteries produce D and L-lactic acids (Figure 1). Absorption of D and L lactic acid through rumen wall results in a decrease in blood $\mathrm{pH}$. A metabolic acidosis occurs due to accumulation of lactic acid (Bolton \& Pass 1988).

Some research reported that high concentrate feeding induces the incidence of sub-acute ruminal acidosis (Mickdam et al. 2016; Wetzels et al. 2016; Sato 2016). Mickdam et al. (2016) studied the effects of feeding 60:40\% grain and forage ratio with NDF content of $31.8 \%$ and Wetzels et al. (2016) investigated feeding $65: 35 \%$ grain and forage ratio with NDF content of $256 \mathrm{~g} / \mathrm{kg}$ and Sato (2016) investigated $80: 20 \%$ of grain and forage ratio. These studies reported the incidence of sub-acute ruminal acidosis. In addition, shifting feeding plane from high forage feeding in week $1(100 \%)$ to $79 \%$ concentrate in week 2 with NDF content of $240 \mathrm{~g} / \mathrm{kg}$ was reported to result in acute acidosis $\mathrm{pH}$ of less than 5 which was observed for 130 minutes (Steele et al. 2009). The aetiology of ruminal acidosis is not only due to high concentrate feeding practices but also pasture feeding with low in neutral detergen fiber (NDF) and high in non-structural carbohydrate (Wales et al. 2001).

Ruminal acidosis is classified as sub-acute ruminal acidosis (SARA) and acute clinical acidosis. Ghozo et al. (2005) determined SARA as rumen $\mathrm{pH}$ at 5.2 and 5.6 for a minimum duration of three hours per day. Different from SARA, acidosis is characterized by a prolong period of $\mathrm{pH}$ decrease below these thresholds (pH <5.0) (Nagaraja \& Lechtenberg 2007). It is worth noting that there are quite a lot of $\mathrm{pH}$ thresholds have been used to illustrate SARA (Plaizier et al. 2008; Zebeli et al. 2008; Gimeno et al. 2015a; Wetzels et al. 2016). Most of the studies mentioned that ruminal $\mathrm{pH}$ dropped between 5.6 and 5.8 for three hours to 5.4 hours per day (Plaizer et al. 2008; Zebeli et al. 2008; Wetzels et al. 2016). Report on various $\mathrm{pH}$ levels of cattle with symptoms of SARA were due to methods and sites of ruminal fluid collection (Duffield et al. 2004; Bramley et al. 2008; AlZahal et al. 2007). Samples collected from oro-ruminal probe showed $\mathrm{pH}$ of 5.9, while rumen canula from ventral sac sample had $\mathrm{pH}$ of 5.8 and sample from rumenocentesis $\mathrm{pH}$ was the lowest (5.5) (Duffield et al. 2004; Bramley et al. 2008; AlZahal et al. 2007). In terms of total VFA, Gimeo et al. (2015a) mentioned that beef cattle could be diagnosed SARA if the total VFA is over $150 \mathrm{mmol} / \mathrm{l}$. The prevalence of acidosis is found in feedlot steers (González et al. 2012) while SARA has reported to affect dairy cattle (Wang et al. 2013; Stefańska et al. 2016).

In addition, high gas production rates of dissolved carbon dioxide (dCO2), the acid in main buffer system 
Increase in fermentable $\mathrm{CHO}$

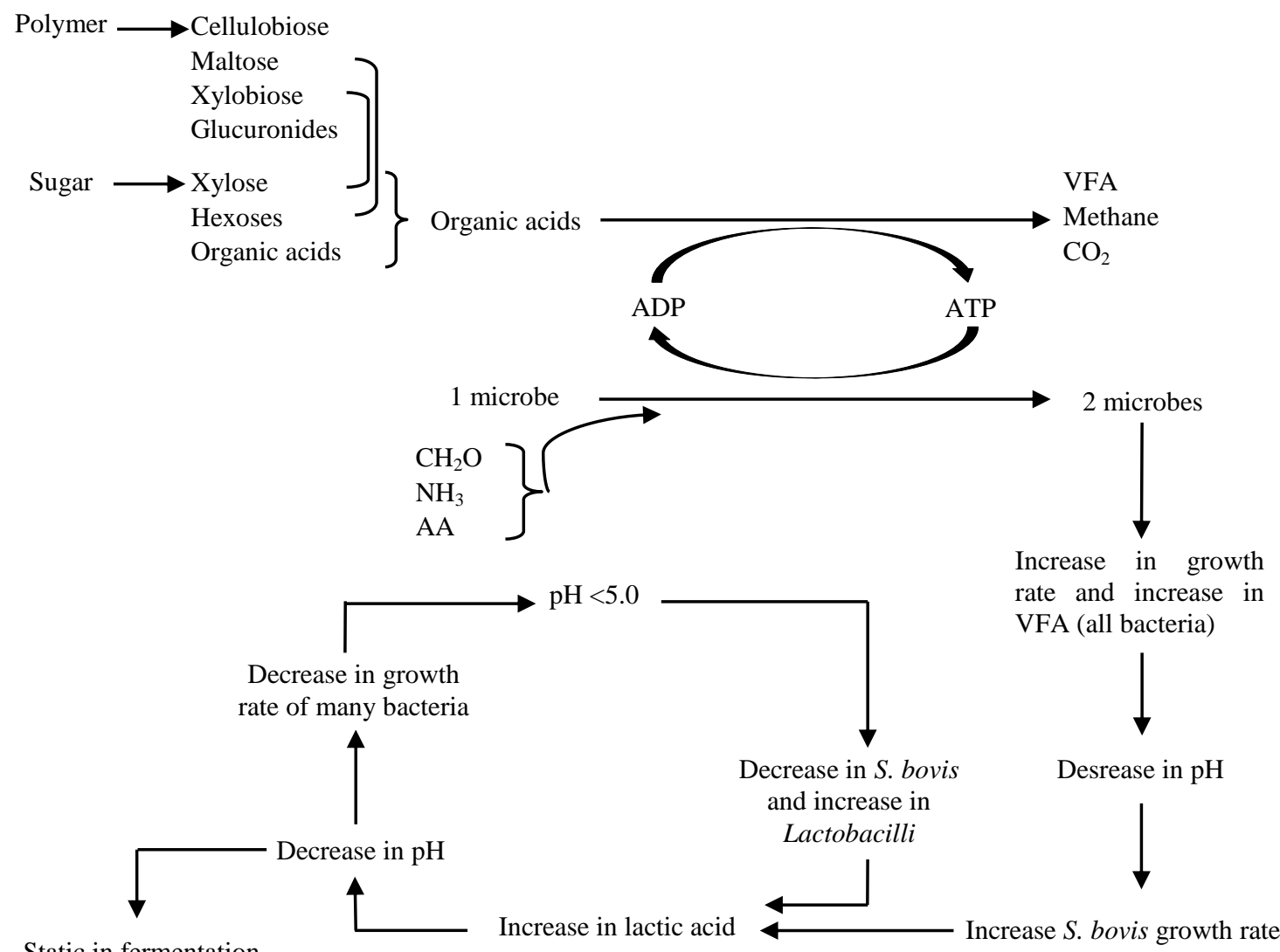

Static in fermentation

$\mathrm{D}$ and $\mathrm{L}$ lactate absorbed

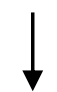

Metabolic acidosis

Figure 1. Sequence of events associated with the onset of acute ruminal acidosis

Source: Baldwin \& Allison (1983)

of rumen was reported to be attributable to a decline in rumen $\mathrm{pH}$ (Laporte-Uribe 2016). Similarly, there are increments in VFA concentration, molar proportion and production rate in the rumen. Gimeno et al (2015a) studied effects of cereal source (maize and barley) and processing (ground and pelleting) on molar proportion of VFA. Their study revealed that in comparison to maize concentrate, barley concentrate decreases acetic acid measured eight hours after meal (501 vs 442 $\mathrm{mmol} / \mathrm{mol}$ ). In contrast, the propionic acid increased (325 vs $409 \mathrm{mmol} / \mathrm{mol}$ ). Insignificant results were reported on butyric acid. Laporte-Uribe (2016) concluded that $\mathrm{dCO}_{2}$ concentration the rumen is more responsible for the increment of rumen acidity.

Feeding high concentrate diet and low forage diet generate a high amount of highly fermentable diet; thus shift the homeostatic rumen microbes (Metzler-Zebeli et al. 2013). Li et al. (2014c) reported that feeding high concentrate resulted in an increase in amylolytic bacteria and a decrease in cellulolytic bacteria. In a severe SARA, population of fibriolytic bacteria of Ruminococcus albus and Fibrobacter succinogenes were reported to decrease. In contrast, genus Prevotella, Lactobacillus group, Megasphaera elsdenii, and Entodinium spp were abundant (Mickdam et al. 2016). A study on feeding dietary induced SARA in dairy goat revealed that an increase in amylolityc bacteria resulted in reduces on dietary NDF and protein degradation. In contrast, an increase in amylolityc bacteria led to increases in starch degradation ( $\mathrm{Li}$ et al. 2014a). In addition, Mickdam et al. (2016) found a decrease in methane gas production by $70 \%$. Kljak et 
al. (2017) reported that methanogenic bacteria are responsible for ruminal methane gas production. Increases in population of Prevotella spp and Prevotella briyantii had resulted in a reduce methanogenic archaea as well as total bacteria, hence a massive drop of methane.

Moreover, Fernando et al. (2010) mentioned that phylum Fibrobacteres are higher in hay-fed ruminant; whereas, a high grain-fed ruminant has higher population of phylum Bacteroidetes. The population of Butyrivibrio fibriosolven and Fibrobacter succinogenes decreases when the ruminants are adapted to high grain diets. AlZahal et al. (2017) reported that an alteration from feeding high forage diet to high grain diet caused a changes in abundance of bacterial microbe community and structure. Rumen bacterial activity, growth and metabolism might be affected by changes of rumen liquid physicochemical properties and $\mathrm{dCO} 2$ concentration bring out by certain diets (Laporte-Uribe 2016).

Rumen epithelium undergoes changes in response to high lipopolysaccharides concentration supplied from high concentrate diet. Tao et al. (2017) reported a mucosal damage where increases of ruminal cells apoptosis were observed in goats fed with high concentrate diet. In addition, there were substantial disturbance in tight junction of ruminal epithelium observed in goats (Liu et al. 2013).

\section{PREVENTING AND CONTROLLING THE RISKS OF SARA}

The success of reducing prevalence of ruminal acidosis due to high concentrate diet can be achieved by particular attention on ruminal mucosa adaptation (Zebeli et al. 2015) as well as microflora adaptation to high energy density diet fermentation in the rumen (Górka et al. 2017). Studies on changes of dietary from high forage diet to high concentrate diet in early post partum dairy cattle were reported to induce SARA. This is because during dry period the dairy cattle is given high fiber diet, hence shorter papillae and less developed ruminal mucosa are observed (Steele et al. 2015). It is reported that during its adaptation to high grain diet, ruminal papillae increases to enlarge its surface area with particular role of insulin-like growth factor (IGF) axis for maximum absorption of ruminal fermentation product (Steele et al. 2012). Therefore, ability of rumen papillae to adapt with rapid increase of SCFA production is vital to minimize negative effects of feeding high concentrate diet.

Calsamiglia et al. (2012) mentioned that prevention of SARA or high-concentrate syndrome can be done through controls of type of diet and $\mathrm{pH}$. The aim of controlling types of dietary given is to increase population of lactic acid consuming microbes such as
Megasphaera elsdenii and Selenomonas ruminantium. Utilization of extracts from several plants such as Acacia or Kennedia had reported to inhibit major lactate producers in the rumen with less detrimental effects to the rumen ecology (Hutton et al. 2012). Thus bioactive plants utilization may be useful to mitigate lactic acidosis in ruminants.

On the other hand, the lactic acid producer such as Streptococcus bovis should be diminished to lessen risks of acidosis in high concentrate feeding. One of the strategies to reduce incidence and prevalence of SARA in cattle is to apply adaptation of feeding high grain diet (Enemark 2009; Fernando et al. 2010). The adaptation facilitates an establishment of stabilization in population and structure of microbes. Kaur et al. (2008) stated that discontinuous feeding pattern of high forage and high concentrate may be effective for nutrient utilization with minimal risks of metabolic disorder. Duration of feeding high grain diet was reported to affect SCFA production and absorption, and induce saliva secretion to recover from low ruminal $\mathrm{pH}$ (Schwaiger et al. 2013).

Some dietary strategies and management such as feeding different type, amount and processing of grain are attributable to control the incidence of SARA. Grains and processed grains have differences in fermentation rates and those that have higher rates of fermentation have a greater tendency to induce acidosis (Gimeno et al. 2015a; 2015b). In comparison to maize, barley has a more rapid degradable rate and is coupled with greater intake (2.83 and $2.43 \mathrm{~kg} \mathrm{DM})$, has led to a more abrupt rumen fermentation. Therefor feeding maize is more preferable to prevent acidosis (Gimeno et al. 2015b). In addition, grinding maize is advisable over pelleting maize to prevent SARA in beef cattle (Gimeno et al. 2015a). Another strategy to minimize the risk is to blend the high rate fermentation grains with the lower ones (Britton \& Stock 1987).

Similarly, inclusion of dietary fiber is functional to avoid acidosis and SARA incidence in ruminants fed with high concentrate. Provision of dietary fiber has been reported to support efficient rumen metabolism (Wang et al. 2017a) as well as indicator for rumen fill (Huhtanen et al. 2016). The amount of DM that is filtered by using a $1.18 \mathrm{~mm}$ screen multiplied by NDF has been useful to predict chewing, secretion of saliva and buffering capacity of rumen (Zebeli et al. 2012b). Furthermore, Esmaeili et al. (2016) revealed that some measurements on physics of fiber so called geometric mean particle length, physical effective neutral detergent fiber of 1.18 (PeNDF 1.18), $19 \mathrm{~mm}$ TMR fraction measured with Penn State Particle Separator were shown to be effective to predict bio-physical responses of dairy herds. It is important to note that feeding dietary fiber is costly because energy cost of chewing is a loss of metabolisable energy used to 
support production performance (Suzuki et al. 2014). Even though dietary fiber is vital to support rumen homeostasis, predicting the minimum requirement of dietary fiber of individual animal is still a challenge. Thus incidence and prevalence of acidosis and SARA exist in cattle farms with high concentrate feeding plane.

Rumination cessation and subsequent decrease in saliva secretion indicate that low buffering capacities occur in rumen environment fed with high starch diets. In order to maintain an ideal rumen $\mathrm{pH}$, addition of dietary buffers can be solutions to improve ruminal digestion when high grain diets are fed to ruminants. Some compounds such as sodium bicarbonate, calcium carbonate, or magnesium oxide are used to reduce acidic rumen environment. Paton et al. (2006) mentioned that sodium bicarbonate supplementation did not reduce SARA in cattle fed-high concentrate diet. Russel \& Chow (1993) explained that these compounds are not likely to have such a buffering effect on ruminal $\mathrm{pH}$ because of the predominant effect of rumen transfer of $\mathrm{CO}_{2}$ from blood. In addition, supplementation of bicarbonates is reported to lower concentration of acids in the rumen. Another possible diet manipulation is to use chemical additives such as the antibiotic ionophores monensin or lasalocid, or biological additive such as live yeast cultures. Ionophores counter gram positive bacteria such as $S$. bovis and lactobacilli, which are the main lactate producers in the rumen. At the same time they stimulate the pathway of propionate production from lactate. These effects explain why ionophores were used to prevent lactic acidosis (Nagaraja et al. 1981). However, because of their antibiotic activity, the use is strictly controlled.

Manipulation by shifting the site of starch digestion is also possible to be applied to limit negative effects of highly fermentable diet. There are factors to concerns such as type of grains or by processing to protect or increase the availability of dietary starch to the microbial digestion in the rumen. An alteration of microbial activity is also possible to control the intensity and pattern of fermentation through the action of certain feed additives. Some studies purposely fed beef cattle with ruminal undegradable starch. The protected diet is partly digested in the intestine. However, because ruminally undegraded starch is partly digested in the intestine, the rate and efficiency of weight gain does not always clearly respond (Streeter et al. 1990). Although it is relatively easy to increase starch ruminal degradation, limiting this degradation is even more difficult.

A method to increase starch ruminal by-pass is by formaldehyde treatment which increases the resistance of protein endosperm to microbial attack and shelters starch granules from microbial digestion (McAllister et al. 1992). Its efficiency is greater with highly degradable starches (Michalet-Doreau et al. 1997) for which the risk of acidosis is greatest. However, the toxicity of formaldehyde sets a limit to its use in animal fed. It can be concluded that almost all detrimental effects associated with feeding high grain diets cannot be fully addressed.

Thus, utilizing the goodness of fiber in maintaining ruminal $\mathrm{pH}$ and supporting animal productivity as well as eliminating the negative effects of dietary fiber to production performance are compulsory. Similarly, feeding high concentrate diet to produce superior animal products with minimum adverse effects on ruminal $\mathrm{pH}$ is a great concern for farmers and cattle industry. A method is urgently needed to answer this problem.

\section{DEVELOPMENT OF RUMEN MECHANICAL STIMULATOR UTILIZATION}

Nutritional disease characterized with low rumen $\mathrm{pH}$ level due to high concentrate feeding has been a major drawback in milk and meat production. A feasible method to reduce risks of digestive related problems with minimum side effects is by adopting mechanical stimulating brush. Rumen mechanical stimulating brush utilization will be beneficial to minimize the negative effects of high concentrate diet in the rumen by copying the stimulation from roughage. Rumen mechanical stimulators stimulate rumen wall that may result in an increase in rumination of the experimental animals. Furthermore, an increase in rumination means an increase in saliva production to buffer acidic environment of rumen. A healthy rumen environment with an optimal $\mathrm{pH}$ level for microbial activity will be positive in improving feed intake, digestibility and metabolizability. These may result in a better production performance, better in production efficiency and health status of the experimental animals.

In general, there are at least three types of rumen mechanical stimulators namely rumen reticulator, pot scrubber and rumenfibe. A rumen reticulator is a nontoxic plastic stick with four tentacles sized 4.5 inch (Figure 2A). A pot scrubber is a bolus-like polypropylene sized $10 \times 7 \mathrm{~cm}$. The installation of the pot scrubbers is by using a stainless speculum diameter $2.54 \mathrm{~cm}$ and a stomach tube (as displayed in Figure 2B). Lastly, a modification of reticulator is a rumen mechanical stimulating brush (Figure 2C). It is synthetic polymer bristles grasped in a metal, $11 \mathrm{~cm}$ in diameter and $10 \mathrm{~cm}$ long, commercially known as Rumenfibe ${ }^{\circledR}$.

Artificial fiber units inserted in the rumen are used to maintain homeostasis condition in the rumen to support production performance by providing 

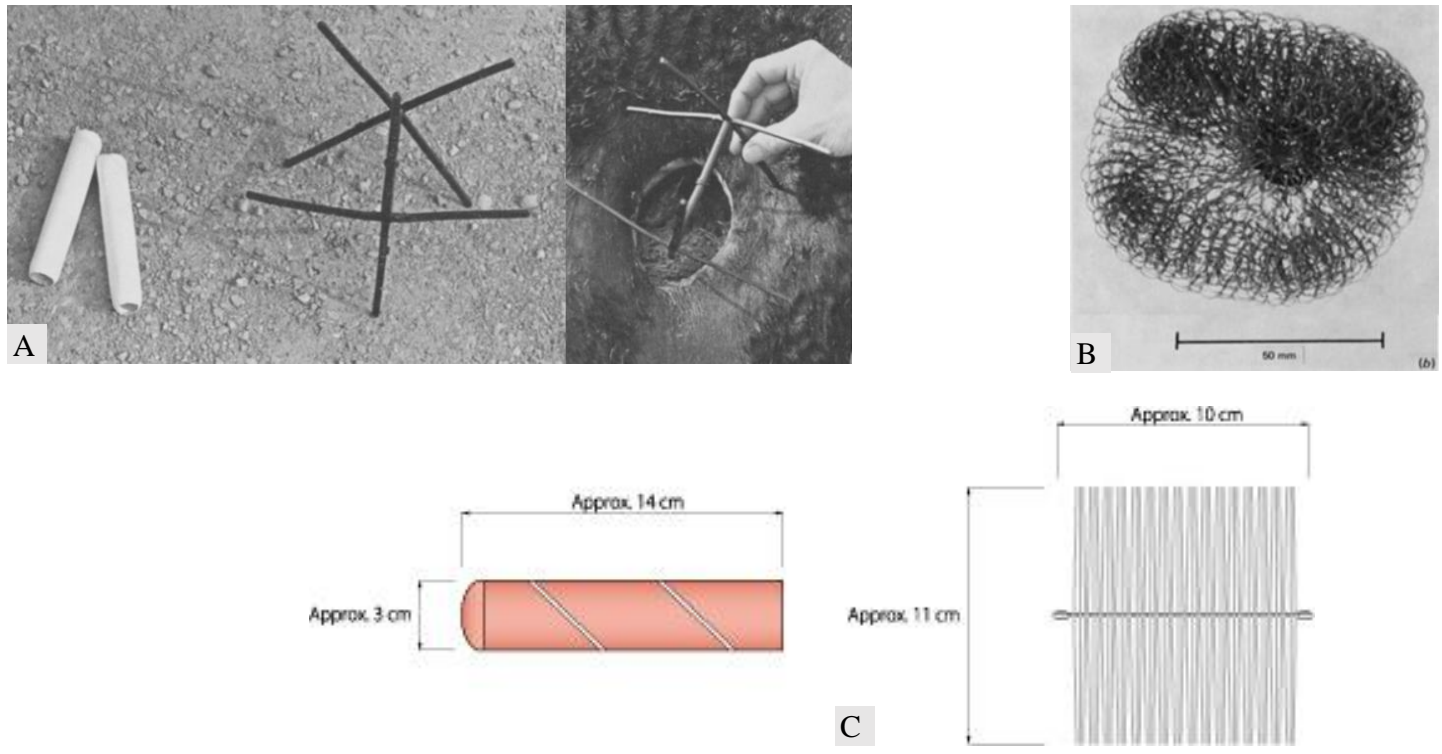

(A) Rumen reticulator; (B) Pot scrubber; (C) Rumen mechanical stimulator brush

Figure 2. Types of rumen mechanical stimulator

Source: (A) Smith (1971); (B) Loerch (1991); (C) Meiwa Sangyo.co. Ltd

continuous stimulation on rumen wall. Smith (1971) evaluated the effects of administration of units reticulator on feed intake, milk production and milk fat production. Two units of rumen reticulators were inserted into rumen of fistulated dairy cattle that were fed with high concentrate diet. The stimulation induced by rumen reticulator in dairy cattle would increase rumen wall motility. It was hypothesized that the pseudo fiber might replace stimulator function of roughage in the rumen. This study reveals that there were insignificant results on energy intake, milk production and milk fat production. Smith (1971) concluded that rumen mechanical stimulator function of roughage could not be replaced by rumen reticulator. To my best knowledge, this is the only research report on reticulator utilization.

Bolus-like plastic scrubbers' administrations reported different results. Utilization of six plastic pot scrubbers in sheep fed high feeding levels (complete intragastric infusion) reported to prolong rumen motility, overcome low $\mathrm{pH}$ issue of rumen content and perform normal growth (Orskov et al. 1979). In addition, Loerch (1991) mentioned that there is an interaction between pot scrubbers and levels of concentrate in the diet. Administration of pot scrubbers to sheep fed with a-100 per cent concentrate feeding in a short-term period resulted in an increase in ADG. However, a similar treatment in a long-term period of $100 \%$ concentrates feeding reported to decrease ADG with $\mathrm{pH}$ level of below 6 . It is also stated that the administration of pot scrubbers did not affect molar percentages of VFA, dilution rate and volume. It seems likely that pot scrubbers cannot be used as roughage substitution in 100 per cent concentrate feeding. The physical stimulation in rumen epithelial surface generated by the presence of pot scrubbers is remaining unclear.

A recent development and modification of rumen reticulator introduced as a rumen mechanical stimulating brush (Figure 2C). Studies by Japanese workers showed that percentage of dietary fiber given affects the effectiveness of rumen mechanical brushes utilization (Table 1). Evaluation on RMS brushes utilization in Holstein steers fed with different levels of organic cell wall from rice straw (15 and 25\%) by Horiguchi and Takahashi (2002a) showed that none of the portion of OCW affected rumination time and ruminal fluid passage rate. Similar results were reported by Horiguchi \& Takahashi (2003) that used RMS brushes in Holstein steers fed 30\% OCW. Horiguchi \&Takahashi (2002b) reduced the level OCW to $12.7 \%$ and the results showed that administration of rumen mechanical stimulating brushes increased ruminal passage rate and tended to increase propionate production. Nevertheles, there were no differences on ruminal $\mathrm{pH}$, rumination time, and VFA concentration between treated and control groups.

RMS brush administration was reported to alter rumen fermentation indicated by a lower VFA concentration and ammonia nitrogen in a high concentrate diet (93\% rolled barley) fed cattle (Matsuyama et al. 2002). Moreover, steers with RMS brush had a more effective feed utilization by increasing nitrogen retention and decrease energy loss in methane. It was evident that RMS brushes 
WARTAZOA Vol. 27 No. 2 Th. 2017 Hlm. 067-080

Table 1. Effects of RMS brush administration on dry matter digestibility and rumen fermentation parameters

\begin{tabular}{|c|c|c|c|c|c|c|c|c|c|c|c|c|}
\hline Treatment & $\begin{array}{c}\text { DM digestibility } \\
(\%)\end{array}$ & $\begin{array}{c}\text { Nitrogen } \\
\text { retention } \\
\text { (g/MBS } 2 / \text { day) }\end{array}$ & $\begin{array}{c}\text { Rumen } \\
\mathrm{pH}\end{array}$ & $\begin{array}{c}\text { Methane } \\
\text { production } \\
\text { (liter/day) }\end{array}$ & $\begin{array}{l}\text { VFA } \\
(\mathrm{mmol} / \\
100 \mathrm{ml})\end{array}$ & $\begin{array}{l}\text { Acetic } \\
\text { acid }(\%)\end{array}$ & $\begin{array}{l}\text { Propionic } \\
\text { acid }(\%)\end{array}$ & $\begin{array}{c}\text { Butyric } \\
\text { acid }(\%)\end{array}$ & $\begin{array}{l}\text { Rumination } \\
\text { (min/day) }\end{array}$ & $\begin{array}{l}\text { Ruminal passage - } \\
\text { Solid passage } \\
\text { (\%/hour })\end{array}$ & $\begin{array}{l}\text { Ruminal passage - } \\
\text { Liquid passage } \\
\text { (\%/hour) }\end{array}$ & Reference \\
\hline $\begin{array}{l}\text { Control Pangola grass } \\
73.7 \% \text { NDF, } \\
\text { concentrate } 34.5 \% \\
\text { NDF (NDF of diet is } \\
2.3 \mathrm{~kg} / \text { day) }\end{array}$ & 62.2 & 11.0 & & 197.51 & & & & & 310.5 & & & $\begin{array}{c}\text { Angthong et al } \\
\text { (2012) }\end{array}$ \\
\hline $\begin{array}{l}\text { Pangola grass } 73.7 \% \\
\text { NDF, concentrate } \\
34.5 \% \text { NDF (NDF of } \\
\text { diet is } 2.3 \mathrm{~kg} / \text { day) } 1: 1 \\
+ \text { RMS brush }\end{array}$ & 60.9 & 6.7 & & 176.23 & & & & & 331.5 & & & \\
\hline $\begin{array}{l}\text { Control (Timothy hay) } \\
\text { (NDF } 64.3 \% \text { ) }\end{array}$ & $84.0^{\mathrm{a}}$ & & 6.6 & $295.0^{\mathrm{a}}$ & 9.7 & 63 & 16.9 & 13.8 & & 3.9 & 5.4 & $\begin{array}{c}\text { Matsuyama et al } \\
\text { (2004a) }\end{array}$ \\
\hline $\begin{array}{l}\text { Timothy hay + RMS } \\
\text { brush (NDF 67.6\%) }\end{array}$ & $85.2^{\mathrm{b}}$ & & 6.76 & $250.8^{\mathrm{b}}$ & 8.5 & 61.3 & 17.1 & 15.4 & & 4.4 & 6.2 & \\
\hline $\begin{array}{l}\text { Control (Brewer's } \\
\text { grain silage) } \\
\text { (NDF 55.9\%) }\end{array}$ & $79.5^{\mathrm{a}}$ & & 6.96 & $260.0^{\mathrm{a}}$ & 8.3 & 63.7 & 16.2 & 13.9 & & 2.7 & 4.6 & \\
\hline $\begin{array}{l}\text { Brewer's grain silage } \\
\text { + RMS brush } \\
\text { (NDF } 57.9 \% \text { ) }\end{array}$ & $80.4^{\mathrm{b}}$ & & 6.89 & $229.4^{\mathrm{b}}$ & 8.0 & 62.1 & 18.9 & 14.4 & & 3.3 & 5.1 & \\
\hline $\begin{array}{l}\text { Control (Timothy } \\
10 \%, 80 \% \text { rolled } \\
\text { barley, NDF } 24.1 \% \text { ) }\end{array}$ & & & 6.5 & & 10.7 & 42.4 & 35.5 & 14.4 & $124^{\mathrm{a}}$ & 2.6 & $5.4^{\mathrm{a}}$ & $\begin{array}{c}\text { Matsuyama et al } \\
(2004 b)\end{array}$ \\
\hline $\begin{array}{l}\text { (Timothy } 10 \%, 80 \% \\
\text { rolled barley, NDF } \\
24.1 \% \text { ) + RMS brush }\end{array}$ & & & 6.6 & & 8.8 & 45.6 & 40.9 & 8.7 & $214^{\mathrm{b}}$ & 3.4 & $6.8^{\mathrm{b}}$ & \\
\hline
\end{tabular}


Table 2. Effects of RMS brush DMD and rumination, ruminal passage rate

\begin{tabular}{|c|c|c|c|c|c|}
\hline Treatment & $\begin{array}{c}\text { DM } \\
\text { digestibility } \\
(\%)\end{array}$ & $\begin{array}{l}\text { Rumination } \\
\text { (min/day) }\end{array}$ & $\begin{array}{l}\text { Ruminal passage - } \\
\text { Solid passage } \\
(\% / \text { hour })\end{array}$ & $\begin{array}{l}\text { Ruminal passage - } \\
\text { Liquid passage } \\
\text { (\%/hour) }\end{array}$ & Reference \\
\hline $\begin{array}{l}\text { Control }(82 \% \text { concentrate : } \\
18 \% \text { short rice straw } 2 \mathrm{~cm} \text {, } \\
\text { OCW } 30 \%)\end{array}$ & 61.9 & na & na & na & $\begin{array}{l}\text { Horiguchi et al. } \\
\text { (2003) }\end{array}$ \\
\hline $\begin{array}{l}\text { (82\% concentrate : } 18 \% \\
\text { short rice straw } 2 \mathrm{~cm}, \\
\text { OCW } 30 \%)+ \text { RMS brush }\end{array}$ & 62.2 & na & na & na & \\
\hline $\begin{array}{l}\text { Control (concentrate } 93 \% \text { : } \\
\text { roughage } 7 \% \text {, NDF } 23.7 \% \text { ) }\end{array}$ & 82 & na & $2.9^{\mathrm{a}}$ & $5.1^{\mathrm{a}}$ & $\begin{array}{l}\text { Matsuyama et al } \\
\text { (2002) }\end{array}$ \\
\hline $\begin{array}{l}\text { (Concentrate } 93 \% \text { : } \\
\text { roughage } 7 \% \text {, NDF 23.7\%) } \\
+ \text { RMS brush }\end{array}$ & 82.7 & na & $3.7^{\mathrm{b}}$ & $6.1^{\mathrm{b}}$ & \\
\hline $\begin{array}{l}\text { Control } \\
\text { (long rice straw } 30 \mathrm{~cm} \text { ) }\end{array}$ & 61.2 & na & na & na & $\begin{array}{l}\text { Horiguchi et al } \\
\qquad(2002 a)\end{array}$ \\
\hline $\begin{array}{l}30 \mathrm{~cm} \text { long rice straw }+ \\
\text { RMS brush }\end{array}$ & 61.5 & na & na & na & \\
\hline $\begin{array}{l}\text { Control }(83 \% \text { concentrate : } \\
17 \% \text { forage, } 2 \mathrm{~cm} \text { rice } \\
\text { straw, } 25 \% \text { OCW })\end{array}$ & 82.0 & 406.7 & na & na & $\begin{array}{l}\text { Horiguchi et al. } \\
\quad(2002 b)\end{array}$ \\
\hline $\begin{array}{l}(83 \% \text { concentrate }: 17 \% \\
\text { forage, } 2 \mathrm{~cm} \text { rice straw, } \\
25 \% \mathrm{OCW})+\mathrm{RMS} \text { brush }\end{array}$ & 82.7 & 393 & na & na & \\
\hline $\begin{array}{l}\text { Control }(83 \% \text { concentrate : } \\
17 \% \text { forage, } 30 \mathrm{~cm} \text { rice } \\
\text { straw, } 25 \% \mathrm{OCW})\end{array}$ & na & 403 & na & na & \\
\hline $\begin{array}{l}(83 \% \text { concentrate : } 17 \% \\
\text { forage, } 30 \mathrm{~cm} \text { rice straw, } \\
25 \% \mathrm{OCW})+\mathrm{RMS} \text { brush }\end{array}$ & na & 399.2 & na & na & \\
\hline $\begin{array}{l}\text { Control }(91 \% \text { concentrate : } \\
9 \% \text { forage, } 2 \mathrm{~cm} \text { rice straw, } \\
15 \% \text { OCW })\end{array}$ & na & 291 & 8.3 & na & \\
\hline $\begin{array}{l}(91 \% \text { concentrate }: 9 \% \\
\text { forage, } 2 \mathrm{~cm} \text { rice straw, } \\
15 \% \mathrm{OCW})+\mathrm{RMS} \text { brush }\end{array}$ & na & 283 & 8.3 & na & \\
\hline $\begin{array}{l}\text { Control }(91 \% \text { concentrate : } \\
9 \% \text { forage, } 30 \mathrm{~cm} \text { rice } \\
\text { straw, } 15 \% \mathrm{OCW})\end{array}$ & na & 303 & 8.0 & na & \\
\hline $\begin{array}{l}91 \% \text { concentrate: } 9 \% \\
\text { forage, } 30 \mathrm{~cm} \text { rice straw, } \\
15 \% \text { OCW) + RMS brush }\end{array}$ & na & 279 & 8.3 & na & \\
\hline
\end{tabular}

${ }^{\mathrm{a}, \mathrm{b}}$ Means within study with different superscript differ $(\mathrm{P}<0.05)$; na: Not available

administration did not affect digestibility, total digestible nutrient and ruminal $\mathrm{pH}$. It is important to note that molar proportion of propionate tended to increase, while acetate decreased (Matsuyama et al. 2002).

The efficacy of this veterinary device requires more investigations. Research on RMS brush utilization is scarce and lack of inclusive research reports.

\section{CASES OF ACIDOSIS AND OPPORTUNITY TO PRODUCE A RUMEN MECHANICAL STIMULATORS PROTOTYPE USING INDONESIAN LOCAL RESOURCES}

The prevalence of acidosis has been reported to affect both dairy and beef cattle in many countries all over the world (Nagaraja \& Lechtenberg 2007; Bramley 2008; Wulandari 2015). It was reported that 
the prevalence of sub-clinical ruminal acidosis reaches $10 \%$ of dairy cows in NSW and Victoria, Australia (Bramley 2008). Similarly, nutritional disorder has been stated as the second leading cause of death with prevalence of $14-42 \%$ in beef cattle (Nagaraja \& Lechtenberg 2007). To the best of our knowledge, there is limited publication on metabolic acidosis prevalence in Indonesia. Laminitis and ruminal acidosis have been reported to cause significant loss in a dairy farm in Indonesia. Data on mortality rates due to laminitis in three consecutive years in a dairy farm in Indonesia showed a significant decrease from $40.93 \%$ in 2011 to $29.76 \%$ in 2012 and in 2013 the prevalence of laminitis stabilized at $29.17 \%$ (Wulandari 2015).

Application of RMS in ruminants will be useful to minimize nutritional related problems due to increases in acid and decreases of alkaline levels in the rumen. Substitution of physically effective NDF with RMS aims to generate mechanical stimulation in rumen. This stimulates contraction of rumen wall which in turn promotes more rumination. Through rumination process, saliva supply into the rumen will increase and this is beneficial to overcome acidic rumen problems.

A synthetic fiber application in ruminants is not new in scientific arena. Particularly the rumen mechanical stimulating brush, a brush-like pseudo fiber aims to provide mechanical stimulus to the rumen wall. Studies on its utilizations, reported various results and presented in Table 1 and 2). It is important to consider the diet and length of RMS utilization period factors before installing the RMS to the rumen.

Referring to the principle function of RMS, it is clear that the effective work of RMS depends on level of fiber in the diet. Horiguchi et al. (2002a; 2002b; 2003) studies the effect of RMS brush administration on different forage lenghts $(2$ and $30 \mathrm{~cm}$ ) and organic cell wall percentages $(12.75 ; 15 ; 25$; and $30 \%$ ) (Table 2). An increase in dietary fiber leads to an increase in rumination rate, decrease solid passage rate and nutrient digestibility because of a lower amount of fermentable carbohydrate (Tafaj et al. 2005). Having RMS brushes in the rumen of steers fed with high concentrate and low forage diet $(87 \%$ concentrate : $13 \%$ forage) (Horiguchi et al. 2002b) and 90\% concentrate : 10 forage (Matsuyama et al. 2004) reported increases in rumination time, ruminal contraction frequency, saliva secretion, thus enhancement of ruminal passage rate. These effects have minimized the negative effect of feeding high concentrate diet, and the steers get the benefits from consuming highly fermentable carbohydrate. Mechanical stimulation in the rumen is generated from the presence of dietary fiber. Therefor the RMS brush is needed only if the diet does not provide the minimum standard requirement of fiber; otherwise, it will be attributable to production cost.
Assesment on adequacy of dietary fiber can be through NDF level and eNDF level. The chemical content of the fiber so called NDF is negatively correlated with DMI; whereas, ADF gives adverse effect to digestibility Parish and Rhinehart (2008). Arelovich et al. (2008) analyzed NDF level in dairy and beef cattle's diet. This metadata study found that percentage of NDF in dairy cattle diet is ranging from 22.5-45.8\% DM. whereas in beef cattle, concentrations of NDF are from 7.5 to $35.3 \%$ DM.

The amount of NDF that is effective in promoting chewing activities, salivation, rumination and motility of rumen is called effective NDF (eNDF). A larger forage particle size creates a more effective physical stimulation or abrasive action in the rumen. For example, eNDF levels of grasses drop from $98 \%$ of NDF to $73 \%$ of NDF as the size of the grass reduced to 4 inches (Parish 2007). Both NDF and eNDF information can be accessed in NRC. Beef Cattle NRC $7^{\text {th }}$ Edition 2000 stated that minimum requirement of eNDF for high concentrate feeding beef cattle is 5 to $8 \%$. A proportion of $25 \%$ eNDF is needed to get normal ruminal $\mathrm{pH}$ (5.6 to 5.7), optimal forage digestion and microbial growth (Parish 2007). RMS brush may be efficient to use when there is insufficient level of eNDF found in a diet.

Another reason for effective utilization of RMS brush is the period of utilization. Administration of RMS brush units means extra money for production cost. Each individual animal requires three units of RMS brush and the installation of the units should be conducted by professional using particular installer tools. The RMS units will stay in the rumen unless the animal is slaughtered and the units are removed. The re-utilization of used RMS units may not be possible. There is pricing for units of RMS. In terms of production cost, the RMS may be economically for a long period of use. Dairy cattle and long term fattening program steers with low forage feeding are preferable. In Indonesia, most of the feedlot steers are fattening for a period-of three months which is short term fattening. Small-holder dairy and beef cattle farmers in Indonesia apply high forage and low concentrate feeding practices. The RMS administration may be beneficial for long term fattening where feeding high concentrate and low forage diet are practiced. There is a shortage indietary fiber in dry season, therefore RMS may be also an option to use in dairy cattle to reduce issues on high energy density diet feeding. RMS brush application is a possible way to minimize the risk of acidosis for long period of dairy and beef cattle farming.

Another factor to consider is stress during the installation process. The farmers as well as the professional technician that conduct the insertion of RMS units should take some precaution steps to 
minimize stress that may be occur during the installation process. A preparation on sterile installer tools and restraining device are another vital thing to have to succeed the installation process. It is also important to do appropriate animal handling because it is not allowed to force the animals to walk forward into the restraining device. This leads to a stress situation of which attributable to a greater loss in production performance. A tempered animal may experience more stress. After the installation process, the animal faces another challenges such as adaptation to the presence of the units as well as adaptation to stimulation by RMS.

High concentrate feeding practices applied in beef cattle and dairy cattle in Indonesia and considering the prevalence of acidosis in dairy cattle farms in Indonesia; therefore, rumen mechanical stimulator is needed to be applied. The challenge in producing RMS using local resources should be taken into action. Indonesia will be able to produce a similar synthetic fiber for material and technology reasons.

RMS, for example Rumenfibe ${ }^{\circledR}$ is a nonpoisonous synthetic and non-digested brush-like stimulator. A similar plastic and metal materials can be produced in Indonesia. The urgency of producing such veterinary device needs assessments on the existing cattle farming practices in Indonesia with particular attentions on supply of dietary fiber and expenditures on the production of the prototype. Having the material available makes it possible for Indonesia to create a prototype of RMS. It is worth noting that some research should be conducted to study the design and the underlying mechanism of RMS functions. A new prototype can be released into a market after a series of research. In the future, a more detail investigation on effects of mechanical stimulation on rumen wall motility and rumination can be conducted and monitored by using RMS completed with a bio-marker.

\section{CONCLUSION}

High concentrate and low forage feeding practices have long been known to lead to nutritional related metabolic problems due to an excessive amount of acid in the rumen that suppress fermentation efficiency and ruminal $\mathrm{pH}$. In order to address this problem, scientists develop RMS. The rumen mechanical stimulator is designed to provide physical stimulation at the rumen wall that is naturally provided by dietary fiber to increase supply of saliva. The functions of RMS in maintaining normal $\mathrm{pH}$ rumen are associated with level of roughage in the ration.

There are at least three kinds of RMS namely rumen reticulator, pot scrubber and rumen mechanical stimulating brush. In particular, RMS brush has been explored and tested for the utilization in beef cattle and dairy cattle farming in several countries.

Potential use of RMS brush in Indonesia needs to be evaluated for dietary fiber adequacy and costs related to RMS brush provision. In the future, utilization of RMS brush with particular biomarkers enables investigation on the tactical stimulation produced by the brush. This is also beneficial for digestive physiology studies.

\section{REFERENCES}

Abdela N. 2016. Sub-acute ruminal acidosis (SARA) and its consequence in dairy cattle: A review of past and recent research at global prospective. Achiev Life Sci. 10:187-196.

AlZahal O, Li F, Guan LL, Walker ND, McBride BW. 2017. Factors influencing ruminal bacterial community diversity and composition and microbial fibrolytic enzyme abundance in lactating dairy cows with a focus on the role of active dry yeast. J Dairy Sci. 100:4377-4393.

AlZahal O, Rustomo B,. Odongo NE, Duffield TF, McBride BW. 2007. Technical note: A system for continuous recording of ruminal $\mathrm{pH}$ in cattle. $\mathrm{J}$ Anim Sci. 85:213-217.

Arelovich HM, Abney CS, Vizcarra JA, Galyean ML. 2008. Effects of dietary neutral detergent fiber on intakes of dry matter and net energy by dairy and beef cattle: Analysis of published data. Prof Anim Sci. 24:375383.

Argov-Argaman N, Mesilati-Stahy R, Magen Y, Moallem U. 2014. Elevated concentrate-to-forage ratio in dairy cow rations is associated with a shift in the diameter of milk fat globules and remodeling of their membranes. J Dairy Sci. 97:6286-6295.

Baldwin RL, Allison MJ. 1983. Rumen Metabolism. J Anim Sci. 57(suppl 2): 461-477.

Baraghit GA, Youssef MM, Ahmed BM, Omar SS, ElMalky OM, 1999. Effect of lasalocid supllementation on nutrients digestibility, rumen fermentation and performance of buffalo calves. Egypt J Nutr Feeds. 2:393-408

Blanco M, Joy M, Alberti P, Ripoll G, Casasus I. 2014. Performance and carcass quality of forage-fed steers as an alternative to concentrate based beef production. Ital J Anim Sci. 13:864-872.

Bolton JR,. Pass DA. 1988. The alimentary tract. Clinicopathologic principles for veterinary medicine. W. F. Robinson and C. R. R. Huxtable. Cambridge, Cambridge University Press: 99-121.

Bramley E, Lean IJ, Fulkerson WJ, Stevenson MA, Rabiee AR, Costa ND. 2008. The definition of acidosis in dairy herds predominantly fed on pasture and concentrates1. J Dairy Sci. 91:308-321. 
Britton RA, Stock RA. 1987. Acidosis, rate of starch digestion and intake. Okla Agric Exp Stn. 121:125137

Calsamiglia S, Blanch M, Ferret A, Moya D. 2012. Is subacute ruminal acidosis a $\mathrm{pH}$ related problem? Causes and tools for its control. Anim Feed Sci Technol. 172:42-50.

de Campeneere S, Fiems LO, de Boever JL, Vanacker JM, de Brabander DL. 2002. Decreasing the roughage: concentrate ratio of a diet to determine the critical roughage part for beef cattle. Archiv für Tierernaehrung. 56:1-12.

Duffield T, Plaizie JC, Bagg R, Vessie G, Dick P, Wilson J, Aramini J, McBride BW. 2004. Comparison of techniques for measurement of rumen $\mathrm{pH}$ in lactating dairy cows. J Dairy Sci. 87:59-66.

Enemark JMD. 2009. The monitoring, prevention and treatment of sub-acute ruminal acidosis (SARA): A review. Vet J. 176:32-43.

Esmaeili M, Khorvash M, Ghorbani GR, Nasrollahi SM, Saebi M. 2016. Variation of TMR particle size and physical characteristics in commercial Iranian Holstein dairies and effects on eating behaviour, chewing activity, and milk production. Livest Sci. 191:22-28

Fernando SC, Purvis HT, Najar FZ, Sukharnikov LO, Krehbiel CR, Nagaraja TG, Roe BA, DeSilva U. 2010. Rumen microbial population dynamics during adaptation to a high-grain diet. Appl Environ Microbiol. 76:7482-7490.

Fruet APB, Stefanello FS, Rosado Júnior AG, Souza ANMd, Tonetto CJ, Nörnberg JL. 2016. Whole grains in the finishing of culled ewes in pasture or feedlot: Performance, carcass characteristics and meat quality. Meat Sci. 113:97-103.

Ghozo GN, Plaizier JC, Krause DO, Kennedy AD, Wittenberg KM. 2005. Subacute Ruminal Acidosis Induces Ruminal Lipopolysaccharide Endotoxin Release and Triggers an Inflammatory Response. J. Dairy Sci. 88:1399-1403.

Gimeno A, Alami AA, Abecia L, de Vega A, Fondevila M, Castrillo C. 2015a. Effect of type (barley vs maize) and processing (grinding vs dry rolling) of cereal on ruminal fermentation and microbiota of beef calves during the early fattening period. Anim Feed Sci Technol. 199:113-126.

Gimeno A, Alami AA, Toral PG, Frutos P, Abecia L, Fondevila M, Castrillo C. 2015b. Effect of grinding or pelleting high grain maize- or barley-based concentrates on rumen environment and microbiota of beef cattle. Anim Feed Sci Technol. 203:67-78.

Gomes MJ, Guedes CM, Silva SR, Azevedo JMT, Dias-daSilva A. 2014. Utilisation of high- and low-roughage diets by a local and an exotic breed of sheep: Intake, growth and digestive efficiency. Livest Sci. 167:110120
González LA, Manteca X, Calsamiglia S, SchwartzkopfGenswein KS, Ferret A. 2012. Ruminal acidosis in feedlot cattle: Interplay between feed ingredients, rumen function and feeding behavior (a review). Anim. Feed Sci Technol. 172:66-79.

Górka P, Schurmann BL, Walpole ME, Błońska A, Li S, Plaizier JC, Kowalski ZM, Penner GB. 2017. Effect of increasing the proportion of dietary concentrate on gastrointestinal tract measurements and brush border enzyme activity in Holstein steers. J Dairy Sci. 100:4539-4551.

Helal FIS, Abdel Rahman KM., Ahmed BM, Omar SS. 2011. Effect of feeding different levels of concentrates on buffalo calves performance, digestibility and carcass traits. American-Eurasian J Agric Environ Sci. 10:186-192

Horcada A, Polvillo O, Juárez M, Avilés C, Martínez AL, Peña F. 2016. Influence of feeding system (concentrate and total mixed ration) on fatty acid profiles of beef from three lean cattle breeds. J Food Composition Analysis. 49:110-116.

Horiguchi K-i, Takahashi T. 2002a. Effects of ruminal administration of mechanical stimulating brush on rumination time and ruminal fluid passage rate in Holstein steers fed concentrate and rice straw. Anim Sci J. 73:495-501.

Horiguchi KI, Takahashi T. 2003. Effects of ruminal dosing of mechanical stimulating brush on digestibility and rumen characteristics of Holstein steers fed high rice straw. Anim Sci J. 74:491-497.

Horiguchi KI, Takahashi T. 2002b. Effect of ruminal dosing of mechanical stimulating brush on rumination time, ruminal passage rate and rumen fermentation status in Holstein steers fed a concentrate diet. Anim Sci J. 73:41-46

Huhtanen P, Detmann E, Krizsan SJ. 2016. Prediction of rumen fiber pool in cattle from dietary, fecal, and animal variables. J Dairy Sci. 99:5345-5357.

Hutton PG, Durmic Z, Ghisalberti EL, Flematti GR, Duncan RM, Carson CF, Riley TV, Vercoe PE. 2012. Inhibition of ruminal bacteria involved in lactic acid metabolism by extracts from Australian plants. Anim Feed Sci Technol. 176:170-177.

Kaur R, Nandra KS, Garcia SC, Fulkerson WJ, Horadagoda A. 2008. Efficiency of utilisation of different diets with contrasting forages and concentrate when fed to sheep in a discontinuous feeding pattern. Livest Sci. 119:77-86

Khafipour E, Li S, Plaizier JC, Krause DO. 2009. Rumen microbiome composition determined using two nutritional models of subacute ruminal acidosis. Appl Environ Microbiol. 75:7115-7124.

Kljak K, Pino F, Heinrichs AJ. 2017. Effect of forage to concentrate ratio with sorghum silage as a source of forage on rumen fermentation, $\mathrm{N}$ balance, and purine 
derivative excretion in limit-fed dairy heifers. J Dairy Sci. 100:213-223.

Laporte-Uribe JA. 2016. The role of dissolved carbon dioxide in both the decline in rumen $\mathrm{pH}$ and nutritional diseases in ruminants. Anim Feed Sci Technol. 219:268-279.

Lascano GJ, Koch LE, Heinrichs AJ. 2016. Precision-feeding dairy heifers a high rumen-degradable protein diet with different proportions of dietary fiber and forageto-concentrate ratios. J Dairy Sci. 99:7175-7190.

Lechartier C, Peyraud JL. 2010. The effects of forage proportion and rapidly degradable dry matter from concentrate on ruminal digestion in dairy cows fed corn silage-based diets with fixed neutral detergent fiber and starch contents. J Dairy Sci. 93:666-681.

Li F, Cao Y, Liu N, Yang X, Yao J, Yan D. 2014a. Subacute ruminal acidosis challenge changed in situ degradability of feedstuffs in dairy goats. J Dairy Sci. 97:5101-5109.

Li F, Li Z, Li S, Ferguson Jd, Cao Y, Yao J, Sun F, Wang X, Yang T. 2014b. Effect of dietary physically effective fiber on ruminal fermentation and the fatty acid profile of milk in dairy goats. J Dairy Sci. 97:22812290.

Li F, Yang XJ, Cao YC, Li SX, Yao JH, Li ZJ, Sun FF. 2014c. Effects of dietary effective fiber to rumen degradable starch ratios on the risk of sub-acute ruminal acidosis and rumen content fatty acids composition in dairy goat. Anim Feed Sci Technol. 189:54-62.

Liu JH, Xu TT, Liu YJ, Zhu WY, Mao SY. 2013. A highgrain diet causes massive disruption of ruminal epithelial tight junction in goats. Am J Physiol Regul Integr Comp Physiol. 305:R232.

Loerch S, Coon, Fluharty F. 1999. Physiological changes and digestive capabilities of newly received feedlot cattle. J Anim Sci. 77:1113-1119.

Loerch SC. 1991. Efficacy of plastic pot scrubbers as a replacement for roughage in high-concentrate cattle diets. J Anim Sci. 69:2321-2328.

Matsuyama H, Horiguchi KI, Takahashi T, Kayaba T, Ishida M, Ando S, Nihida T. 2002. Effects of ruminal dosing of mechanical stimulating brush on digestibility, nitrogen balance, energy balance and rumen characteristics in Holstein steer fed diet containing mainly rolled barley. Anim Sci J. 73:397-405.

McAllister, Rode LM, Cheng KJ, Buchanan-Smith JG. 1992. Effect of formaldehyde-treated barley or escape protein on the ruminal environment and digestion in steers. Can J Anim Sci. 72:317-328.

Michalet-Doreau B, Schmitz-Esser S, Klevenhusen F, Podstatzky-Lichtenstein L, Wagner M, Zebeli Q. 1997. In situ and in vitro ruminal starch degradation of untreated and formaldehyde-treated wheat and maize. Reprod Nutr Dev. 37:305-312.
Metzler-Zebeli BU, Schmitz-Esser S, Klevenhusen F, Podstatzky-Lichtenstein L, Wagner M, Zebeli Q. 2013. Grain-rich diets differently alter ruminal and colonic abundance of microbial populations and lipopolysaccharide in goats. Anaerobe. 20:65-73.

Mickdam E, Khiaosa-ard R, Metzler-Zebeli BU, Klevenhusen F, Chizzola R, Zebeli Q. 2016. Rumen microbial abundance and fermentation profile during severe subacute ruminal acidosis and its modulation by plant derived alkaloids in vitro. Anaerobe. 39:413.

Nagaraja TG, Avery T B, Bartley EE, Galitzer SJ, Dayton AD. 1981. Prevention of lactic acidosis in cattle by lasalocid or monensin. J Anim Sci. 53:206-216.

Nagaraja TG, Lechtenberg KF. 2007. Acidosis in feedlot cattle. Vet Clin North Am Food Anim Pract. 23:3333350 .

Orskov ER, Grubb DA, Wenham G, Corrigall W. 1979. The sustenance of growing and fattening ruminants by intragastric infusion of volatile fatty acid and protein. Br J Nutr. 41:553-558

Parish JA. 2007. Effective fiber in beef cattle diets. Starkville (US): Mississippi State Univ.

Parish JA, Rhinehart JD. 2008. Fiber in beef cattle diets. Starkville (US): Mississippi State Univ.

Paton LJ, Beauchemin KA, Veira DM, von Keyserlingk MAG. 2006. Use of sodium bicarbonate, offered free choice or blended into the ration, to reduce the risk of ruminal acidosis in cattle. Can J Anim Sci. 86:429437.

Plaizier JC, Krause DO, Gozho GN, McBride BW. 2008. Subacute ruminal acidosis in dairy cows: The physiological causes, incidence and consequences. Vet J. 176:21-31.

Russell JB,Chow JM. 1993. Another theory for the action of ruminal buffer salts: decreased starch fermentation and propionate production. J Dairy Sci. 76:826-830.

Sato S. 2016. Pathophysiological evaluation of subacute ruminal acidosis (SARA) by continuous ruminal $\mathrm{pH}$ monitoring. Anim. Sci. Journal 87:168-177.

Schären M, Seyfang GM, Steingass H, Dieho K, Dijkstra J, Hüther L, Frahm J, Beineke A, von Soosten D, Meyer $\mathrm{U}$ et al. 2016. The effects of a ration change from a total mixed ration to pasture on rumen fermentation, volatile fatty acid absorption characteristics, and morphology of dairy cows. J Dairy Sci. 99:3549-3565.

Schoonmaker J, Trenkle A, Beitz D. 2010. Effect of feeding wet distillers grains on performance, marbling deposition, and fatty acid content of beef from steers fed low-or high-forage diets. J Anim Sci. 88:36573665 .

Schwaiger T, Beauchemin KA, Penner GB. 2013. Duration of time that beef cattle are fed a high-grain diet affects the recovery from a bout of ruminal acidosis: Shortchain fatty acid and lactate absorption, saliva 
production, and blood metabolites. J Anim Sci. 91:5743-53.

Smith NE. 1971. Mechanical rumen stimulators. Vet Med Small Anim Clin. 12:4-5.

Snyder E, Credille B. 2017. Diagnosis and treatment of clinical rumen acidosis. 33(3):451-461.

Steele MA, AlZahal O, Hook SE, Croom J, McBride BW. 2009. Ruminal acidosis and rapid onset of ruminal parakeratosis in a mature dairy cow; a case report. Acta Veterinaria Scandinavica 51: 39-45.

Steele MA, Schiestel C, AlZahal O, Dionissopoulos L, Laarman A, Matthews J, McBride B. 2015. The periparturient period is associated with structural and transcriptomic adaptations of rumen papillae in dairy cattle. J Dairy Sci. 98:2583-2595.

Steele MA, AlZahal O, Walpole ME, McBride BW. 2012. Short communication: Grain-induced subacute ruminal acidosis is associated with the differential expression of insulin-like growth factor-binding proteins in rumen papillae of lactating dairy cattle. $\mathbf{J}$ Dairy Sci. 95:6072-6076.

Stefańska B, Nowak W, Komisarek J, Taciak M, Barszcz M, Skomiał J. 2016. Prevalence and consequence of subacute ruminal acidosis in polish dairy herds. J Anim Physiol Anim Nutr. 101:694-702.

Streeter MN, Wagner DG, Hibberd CA, Owens FN (1990) Comparison of corn with four sorghum grain hybrids: site and extent of digestion in steers. J Anim Sci. 68:3429-3440.

Suzuki T, Kamiya Y, Tanaka M, Hattori I, Sakaigaichi T, Terauchi T, Nonaka I, Terada F. 2014. Effect of fiber content of roughage on energy cost of eating and rumination in Holstein cows. Anim Feed Sci Technol. 196:42-49

Tafaj M, Kolaneci V, Junck B, Maulbetsch A, Steingass H, Drochner W. 2005. Influence of fiber content and concentrate level on chewing activity, ruminal digestion, digesta passage rate and nutrient digestibility in dairy cows in late lactation. AsianAustralasian J Anim Sci. 18:1116-112.

Tao S, Duanmu Y, Dong H, Ni Y, Chen J, Shen X, Zhao R. 2014. High concentrate diet induced mucosal injuries by enhancing epithelial apoptosis and inflammantory response in the hindgut of goats. PLoSOne. 9.

Turgeon OA, Szasz JI, Koers WC, Davis MS, Vander Pol KJ. 2010. Manipulating grain processing method and roughage level to improve feed efficiency in feedlot cattle. J Anim Sci. 88:284-295.

Wales WJ, Williams YJ et al. 2001. Effect of garain supplementation and the provision of chemical or physical fiber on marginal milk production responses of cows grazing perennial ryegrass pastures. Australian Journal of Experimental Agriculture $41: 465-471$

Wang B, Wang D, Huang X, Liu JX. 2017a. Effects of dietary physical or nutritional factors on morphology of rumen papillae and transcriptome changes in lactating dairy cows based on three different foragebased diets. BMC Genomics. 18:353.

Wang DS, Zhang RY, Zhu WY, Mao SY. 2013. Effects of subacute ruminal acidosis challenges on fermentation and biogenic amines in the rumen of dairy cows. Livest Sci. 155:262-272.

Wang X, Xie H, Liu F, Wang Y. 2017b. Production performance, immunity, and heat stress resistance in Jersey cattle fed a concentrate fermented with probiotics in the presence of a Chinese herbal combination. Anim Feed Sci Technol. 228:59-65.

Wetzels SU, Mann E, Pourazad P, Qumar M, Pinior B, Metzler-Zebeli BU, Wagner M, Schmitz-Esser S, Zebeli Q. 2016. Epimural bacterial community structure in the rumen of Holstein cows withdifferent responses to a long-term subacute ruminal acidosis diet challenge. J. Dairy Sci. 100:1-16 doi.org/10.3168/jds.2016-11620.

Yang W, Beauchemin K. 2007. Altering physically effective fiber intake through forage proportion and particle length: Chewing and ruminal $\mathrm{pH}$. J Dairy Sci. 90:2826-2838

Zanton GI, Heinrichs AJ. 2016. Efficiency and rumen responses in younger and older Holstein heifers limitfed diets of differing energy density. J Dairy Sci 99:2825-2836.

Zebeli Q, Dijkstra J, Tafaj, M., Steingass, H., Ametaj BN, Drochner W. 2008. Modeling the adequacy of dietary fiber in dairy cows based on the responses of ruminal $\mathrm{pH}$ and milk fat production to composition of the diet. J Dairy Sci. 91:2046-2066.

Zebeli Q, Aschenbach JR, Tafaj M, Boguhn J, Ametaj BN, Drochner W. 2012. Invited review: Role of physically effective fiber and estimation of dietary fiber adequacy in high-producing dairy cattle. J Dairy Sci. 95:1041-1056.

Zebeli Q, Ghareeb K, Humer E, Metzler-Zebeli BU, Besenfelder U. 2015. Nutrition, rumen health and inflammation in the transition period and their role on overall health and fertility in dairy cows. Res Vet Sci. 103:126-136

Zebeli Q, Tafaj M, Weber I, Dijkstra J, Steingass H, Drochner W. 2007. Effects of Varying dietary forage particle size in two concentrate levels on chewing activity, ruminal mat characteristics, and passage in dairy cows. J Dairy Sci. 90:1929-1942. 